\title{
Independensi, Kompetensi, Pelatihan, Pengalaman Kerja, Tingkat Pendidikan dan Kinerja Pengawas Koperasi
}

\author{
Putu Ratih Kartika Dewi ${ }^{1}$ \\ Fakultas Ekonomi dan Bisnis \\ Universitas Udayana, Indonesia
}

\author{
Made Yenni Latrini ${ }^{2}$ \\ Fakultas Ekonomi dan Bisnis \\ Universitas Udayana, Indonesia
}

Surel : ratihkartikaa07@gmail.com

\section{ABSTRAK}

Peran pengawas koperasi sebagai pengendalian intern koperasi sangatlah penting dimana pengawas koperasi bertugas mengawasi jalannya operasional koperasi dan membantu agar sasaran yang ditetapkan koperasi dapat tercapai. Penelitian ini bertujuan untuk mengetahui pengaruh independensi, kompetensi, pelatihan, pengalaman kerja, dan tingkat pendidikan pada kinerja pengawas koperasi di Kecamatan. Buleleng. Jumlah sampel dalam penelitian ini adalah sebanyak 79 responden. Metode yang digunakan adalah metode purposive sampling. Penelitian menunjukkan bahwa semua variabel memberikan pengaruh positif pada kinerja pengawas. Penelitian ini sekaligus mengkonfirmasi teori yang digunakan yaitu teori atribusi.

Kata Kunci: Independensi; Kompetensi; Pelatihan; Pengalaman Kerja; Tingkat Pendidikan.

The Influence of Independence, Competence, Training, Work Experience and Education Level on Cooperative Supervisory Performance

\footnotetext{
ABSTRACT

The role of supervisors as cooperative internal auditors is very important. Supervisors are tasked with supervising the operations of the cooperative and helping to achieve the goals set by the cooperative. This study aims to determine the effect of independence, competence, training, work experience, and education level on the performance of cooperative supervisors in Buleleng District. The number of samples in this study were 79 respondents. The analysis technique used is multiple linear regression. Research shows that all variables have a positive influence on supervisor performance. This study confirms the attribution theory.
}

Keywords: $\quad$ Independence; Competence; Training Work Experience; Education Level.

Artikel dapat diakses : https://ojs.unud.ac.id/index.php/Akuntansi/index

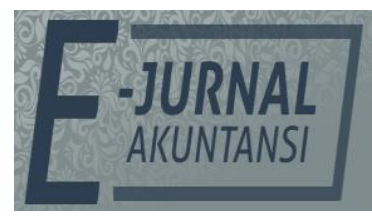

e-ISSN 2302-8556

Vol. 30 No. 12

Denpasar, Desember 2020

Hal. 3162-3175

DOI:

10.24843/EJA.2020.v30.i12.p13

PENGUTIPAN:

Dewi, P.R.K. \& Latrini, M.Y. (2020). Independensi, Kompetensi, Pelatihan, Pengalaman Kerja, Tingkat Pendidikan dan Kinerja Pengawas Koperasi. E-Jurnal Akuntansi, 30(12), 3162-3175

RIWAYAT ARTIKEL: Artikel Masuk: 24 Juli 2020 Artikel Diterima: 9 Desember 2020 


\section{PENDAHULUAN}

Koperasi merupakan suatu organisasi yang terdiri dari beberapa orang dengan visi misi yang sama untuk memberikan kesejahteraan pada masing- masing anggotanya. Koperasi dibentuk bukan hanya bertujuan untuk mencari keuntungan (laba) tetapi juga bertujuan untuk memberikan pelayanan yang dapat mensejahterakan anggota khususnya dan masyarakat pada umumnya. Koperasi diharapkan mampu mengurangi kesenjangan sosial yang ada di masyarakat. (Kalbers, 1995)Pentingnya keberadaan koperasi mengharuskan koperasi melakukan usaha yang baik terus dapat bersaing sehingga koperasi memerlukan yang namanya auditor internal. Dengan adanya auditor internal dapat memastikan bahwa segala bentuk resiko yang terjadi dapat dikelola maksimal. Tujuan dari adanya internal audit adalah untuk membantu manajemen organisasi dalam memberikan pertanggungjawbaan yang efektif.

Pasal 38 Undang-Undang No 25 Tahun 1992 tentang perangkat organisasi, pengawas dipilih oleh dari anggota koperasi dalam Rapat Anggota Tahunan (RAT). (Akbar, 2019) Pengawas koperasi merupakan anggota koperasi yang telah dipilih untuk melakukan fungsi pengawasan terhadap operasional koperasi. Peran pengawas sebagai auditor internal koperasi bertugas mengawasi jalannya operasional koperasi sesuai dengan target yang telah ditetapkan dalam RAT. Pengawas koperasi bertugas dalam memeriksa catatan, pembukuan tahunan koperasi, mengevaluasi pelaksanaan anggaran, dan mengawasi kinerja pengurus lainnya. Hasil pemeriksaan pengawas kemudian disampaikan kepada para anggota untuk dikaji lebih lanjut. Diharapkan dengan adanya monitor dari tim pengawas koperasi maka jalannya koperasi akan lebih teratur dan sesuai kesepakatan dalam RAT.

Fenomena yang diamati dalam permasalahan yang muncul pada koperasi di Bali adalah maraknya pembubaran sejumlah koperasi. Permasalahan tersebut tidak lepas dari lemahnya pengelolaan koperasi. Tahun 2018 koperasi di Bali berjumlah 4.850 koperasi sebanyak 567 koperasi dinyatakan tidak aktif dan 169 koperasi dinyatakan dibubarkan karena pengelolaan koperasi yang buruk atau kurang terlaksana dengan baik (Nusabali. com). Buleleng merupakan salah satu Kecamatan di Bali yang perkembangan koperasinya masih perlu dilakukan pembinaan. Tabel 1, menyatakan data koperasi di Kecamatan Buleleng tahun 2016 sampai tahun 2018.

Tabel 1. Data Koperasi di Kecamatan Buleleng Tahun 2016-2018

\begin{tabular}{llccc}
\hline No & Uraian & \multicolumn{3}{c}{ Jumlah Koperasi } \\
\cline { 3 - 5 } & & 2016 & 2017 & 2018 \\
\hline 1 & Jumlah Koperasi & 141 & 147 & 155 \\
2 & Tidak Aktif & 23 & 25 & 30 \\
3 & Aktif & 118 & 122 & 125 \\
4 & RAT & 97 & 106 & 102 \\
\hline
\end{tabular}

Sumber: Data Penelitian, 2018

Dilihat dari Tabel 1, bahwa di Kecamatan Buleleng jumlah koperasi meningkat setiap tahunnya namun bersamaan dengan meningkatnya jumlah koperasi yang tidak melaksanakan RAT. Berikut ini merupakan table perkembangan status tingkat Kesehatan koperasi yang ada di Kecamatan Buleleng. 
Tabel 2. Data Status Tingkat Kesehatan Koperasi di Kecamatan Buleleng

\begin{tabular}{ccccccc}
\hline Tahun & Sehat & $\begin{array}{c}\text { Cukup } \\
\text { Sehat }\end{array}$ & $\begin{array}{c}\text { Kurang } \\
\text { Sehat }\end{array}$ & $\begin{array}{c}\text { Tidak } \\
\text { Sehat }\end{array}$ & $\begin{array}{c}\text { Tidak } \\
\text { Operasi }\end{array}$ & $\begin{array}{c}\text { Persen } \\
(\%)\end{array}$ \\
\hline 2016 & 92 & 9 & 6 & 14 & 23 & 65,2 \\
2017 & 87 & 11 & 9 & 15 & 25 & 61,2 \\
2018 & 83 & 11 & 12 & 19 & 30 & 57,4 \\
\hline
\end{tabular}

Sumber: Dinas Koperasi dan UMKM Kabupaten Buleleng, 2018

Dilihat dari Tabel 2, Tingkat kesehatan koperasi di Kecamatan Buleleng dari tahun 2016-2018 mengalami penurunan. Koperasi tidak sehat merupakan kondisi dimana koperasi mempunyai kinerja pengawas yang kurang baik. Kondisi tersebut disebabkan kinerja pengawas yang masih kurang sehingga bisa saja terjadi penyelahgunaan wewenang yang dilakukan oleh beberapa bagian seperti pengurus, manajer, dan karyawan lain yang bekerja dikoperasi tersebut. Koperasi yang tidak sehat rentan terjadinya pembubaran koperasi. Pengawas koperasi maka dari itu dituntut untuk memiliki sikap independensi.

Independensi merupakan sikap bebas yang tidak dipengaruhi dan tidak terikat dengan pihak lain. Seorang pengawas hendaknya memiliki kemandirian dalam dirinya sendiri untuk menghindari pendapat bias yang mungkin diberikan. Indenpendensi merupakan modal awal bagi seorang auditor dan sangat penting dimilikinya (Afroz, 2018). (Bliss et al., 2017) pengawas koperasi selain memiliki sikap independensi dalam melaksanakan tugasnya ia juga harus memiliki kompetensi yang layak dalam bidangnya.

Kompetensi merupakan suatu hal yang dikaitkan dengan pengetahuan, kemampuan, dan keterampilan yang dijadikan acuan dalam melakukan tanggungjawab pekerjaan yang berhubungan langsung terhadap kinerjanya (Agustia \& Pertiwi, 2013). (Kartika \& Sugiarto, 2014) kompetensi seorang pengawas dapat ditingkatkan dengan sering adanya program pelatihan dimana pelatihan merupakan cara untuk mencapai profesionalisme kerja. Pelatihan merupakan salah satu cara efektif untuk meningkatkan kemampuan pengawas. Pelatihan sesungguhnya bertujuan untuk meningkat nilai dan kualitas para pengawas. (Bhat, 2013) pelatihan yang teratur yang diberikan kepada pengawas sebagai auditor internal koperasi mengenai berbagai macam perkembangan dalam dunia audit dapat menambah wawasan dan meningkatkan profesionalismenya. (Badara \& Saidin, 2013) rajin mengikuti pelatihan seorang pengawas sebaiknya juga telah memiliki beberapa pengalaman kerja dibidangnya. (Bouhwai M \& Zaki, 2015) seorang pengawas memiliki banyak pengalaman akan terlatih untuk berhadapan dalam setiap situasi kerja, dan akan lebih cepat tanggap dalam mendeteksi kecurangan. Pengalaman kerja yang memadai juga harus didikung dengan tingkat pendidikan yang tinggi. (Cloyd \& C Bryan, 1997) menyatakan bahwa tingkat pendidikan seseorang dapat meningkatkan kualitas kerja. Semakin tinggi pendidikan auditor semakin memiliki wawasan yang lebih luas sejalan dengan bidang profesinya, dan memiliki kompetensi yang cukup untuk mempraktekannya dalam kerja nyata. Penelitian ini bertujuan untuk mengetahui dan menguji adanya pengaruh independensi, kompetensi, pelatihan, pengalaman kerja, dan tingkat pendidikan pada kinerja pengawas koperasi di Kecamatan Buleleng. 
Teori atribusi yaitu teori yag mempelajari alasan atas perilaku seseorang. Independensi merupakan faktor internal penyebab perilaku seorang pengawas. Independensi merupakan sikap yang paling penting yang harus dimiliki seorang pengawas. Setiap pengawas harus memiliki integritas dan obyektifitas dalam tugasnya. Sikap independensi dirasa sangat penting dalam melaksanakan pengawasan yang efektif yang nantinya akan berpengaruh terhadap kinerja pengawas sebagai fungsi auditor internal.

Penelitian yang dilakukan oleh (Putu \& Desyanti, 2008) menyatakan bahwa variabel independensi berpengaruh positif terhadap kinerja auditor. (Alim et al., 2007) dalam penelitiannya menyebutkan bahwa independensinya berpengaruh positif terhadap kualitas audit dan (Allen et al., 2005) (Bullen \& Eyler, 2010) juga menyatakan bahwa semakin baik sikap independensi yang dimiliki auditor maka semakin baik pula kinerjanya. Semakin tinggi pengawas memiliki sikap independensi maka akan semakin baik kinerja yang dihasilkan.

$\mathrm{H}_{1}$ : Independensi berpengaruh positif terhadap kinerja pengawas koperasi.

Teori atribusi yaitu teori yang mempelajari alasan atas perilaku seseorang. Kompetensi merupakan faktor internal penyebab perilaku seorang pengawas. Pengawas dituntut untuk memiliki kompetensi yang baik agar mempermudah pengawas dalam mengawasi jalannya operasional koperasi. Seorang pengawas akan menghasilkan kinerjanya yang optimal apabila memiliki kompetensi yang sesuai dengan bidangnya. (Alim et al., 2007) dan (Dewi, 2013) menemukan bahwa kompetensi berpengaruh positif terhadap kualitas audit. (Putra \& Rasmini, 2014) menyatakan bahwa kompetensi berpangruh positif pada efektivitas pengendalian intern koperasi. (Tjun et al, 2012) dan (Ferracuti \& Stubben, 2019) menyatakan bahwa kompetensi berpengaruh positif terhadap kualitas audit. Semakin baik kompetensi yang dimiliki pengawas maka akan semakin berpengaruh terhadap hasil pemerikasaannya.

$\mathrm{H}_{2}$ : Kompetensi berpengaruh positif terhadap kinerja pengawas koperasi.

Teori atribusi yaitu teori yang mempelajari alasan atas perilaku seseorang. Pelatihan merupakan faktor internal penyebab perilaku seorang pengawas. Pengawas merupakan suatu cara yang efektif untuk dapat meningkatkan kualitas kemampuan pengawas. Pelatihan memiliki berperan yang sangat penting terhadap hasil kerja yang dihasilkan pengawas koperasi selaku auditor internal. Pelatihan sama halnya juga dengan pendidikan yaitu cara untuk mencapai profesionalisme kerja (Afroz, 2018). Adanya pelatihan bisa lebih memperluas pengetahuan dan kerampilan guna menciptakan pekerjaan yang lebih profesional, efektif dan efesien guna mempermudah pengawas dalam mengawasi jalannya operasional koperasi.(Putra \& Rasmini, 2014) menyatakan pelatihan perpengaruh positif terhadap kinerja pengawas. (Andayani \& Makian, 2016) dan (Sofia \& Murwaningsari, 2019) juga mengemukakan bahwa pelatihan berpengaruh positif terhadap kinerja karyawan.

$\mathrm{H}_{3}$ : Pelatihan berpengaruh positif terhadap kinerja pengawas koperasi.

Teori atribusi yaitu teori yang mempelajari alasan atas perilaku seseorang. Pengalaman kerja merupakan faktor internal penyebab perilaku seorang pengawas. Pengalaman kerja merupakan suatu cara yang efektif untuk dapat meningkatkan kualitas kemampuan pengawas. Pengalaman kerja merupakan sesuatu yang penting yang harus dimiliki seorang pengawas. 
Pengawas yang memiliki pengalaman kerja yang lebih akan lebih tanggap dalam menjalankan tugasnya terutama dalam medeteksi kekeliruan atau kecurangan yang terjadi dan pengawas akan lebih bisa menghasilkan kinerja yang optimal dengan memiliki pengalaman kerja yang lebih. Penelitian yang dilakukan oleh (Budiasih \& Budiartha, 2017) mengemukakan bahwa pengalaman kerja berpengaruh positif pada kinerja auditor. (Kodyawati \& Dewi, 2019) dan (Prawitasari \& Badera, 2015) menyatakan pengalaman kerja berpengaruh berpengaruh positif terhadap kinerja karyawan.

$\mathrm{H}_{4}$ : Pengalaman kerja berpengaruh positif terhadap kinerja pengawas koperasi.

Teori atribusi yaitu teori yang mempelajari alasan atas perilaku seseorang. Tingkat pendidikan merupakan faktor internal penyebab perilaku seorang pengawas. Tingkat pendidikan sangat dibutuhkan dalam profesi profesional apapun. Pendidikan membantu seorang untuk mendapatkan pengetahuan yang berguna bagi tugas yang akan dilakukan. Pengawas yang mempunyai pendidikan yang memadai akan mempunyai keterampilan dalam pelaksanaan kerja. Penelitian yang dilakukan oleh (Widyantara, Wahyuni, \& Atmadja, 2017) menyatakan tingkat pendidikan berpangaruh positif terhadap kinerja badan pengawas LPD di Kecamatan Buleleng. (Kodyawati \& Dewi, 2019) dan (Murtini \& Juliarsa, 2017) dalam penelitiannya juga menyatakan bahwa tingkat pendidikan berpengaruh positif terhadap kinerja pengawas. Pendidikan yang dimiliki pengawas dan sesuai dengan bidang pekerjannya akan lebih mempermudah pengawas dalam melakukan pemeriksaan audit.

$\mathrm{H}_{5}$ : Tingkat pendidikan berpengaruh positif terhadap kinerja pengawas koperasi

\section{METODE PENELITIAN}

Penelitian ini dilakukan diseluruh koperasi yang ada di Kecamatan Buleleng. Lokasi tersebut dipilih karena koperasi di Kecamatan Buleleng berdasarkan data jumlah koperasi Tahun 2016-2018 jumlah koperasi bertambah tetapi bersamaan dengan jumlah koperasi yang dibubarkan serta berdasarkan status kesehatan koperasi. Obyek dalam penelitian ini adalah Kinerja Pengawas Koperasi Di Kecamatan Buleleng yang dilihat dari Independensi, Kompetensi, Pelatihan, Pengalaman Kerja, dan Tingkat Pendidikan yang dimilikinya. Data kuantitatif yaitu data jumlah koperasi yang ada di Kecamatan Buleleng. Data kualitatif yaitu berupa pendapat responden terhadap pertanyaan atau pernyataan yang terdapat dalam kuesioner. Sumber data yang digunakan adalah data primer dan data skunder. Data primer dalam penelitian ini adalah tanggapan dari responden terkait kuesioner yang telah diberikan, sedangkan data skunder dalam penelitian ini adalah data tentang jumlah koperasi yang ada di Kecamatan Buleleng. Metode penentuan sampel yang digunakan dalam penelitian ini adalah dengan teknik purposive sampling. Jumlah populasi penelitian ini sebanyak 27 koperasi dan 81 responden. Adapun kriteria-kriteria dalam penentuan sampel: 1) Pengawas telah bekerja minimal selama dua tahun atau lebih 2) Pengawas sudah memiliki latar belakang pendidikan dibidang akuntansi.

Penelitian ini menggunakan Teknik regresi linier berganda. Teknk ini digunakan untuk mengetahui pengaruh antara variabel bebas terhadap variabel terikat, yaitu independensi, kompetensi, pelatihan, pengalaman kerja, dan tingkat pendidikan pada kinerja pengawas koperasi di Kecamatan Buleleng. 
Model persamaannya dapat digambarkan sebagai berikut.

$Y=\alpha+\beta 1 X_{5}+\beta 2 X_{2}+\beta 3 X_{3}+\beta 4 X_{4}+\beta X_{5}+\varepsilon$

Keterangan:

Y: Kinerja pengawas koperasi

$\mathrm{X}_{1}$ : Independensi

$\mathrm{X}_{2}$ : Kompetensi

$\mathrm{X}_{3}$ : Pelatihan

$\mathrm{X}_{4}$ : Pengalaman Kerja

$\mathrm{X}_{5}$ : Tingkat Pendidikan

$\beta_{1}$ : Koefisien Independensi

$\beta_{2}$ : Koefisien Kompetensi

$\beta_{3}$ : Koefisien Pelatihan

$\beta_{4}$ : Koefisien Pengalaman Kerja

$\beta_{5}$ : Koefisien Tingkat Pendidikan

$a:$ Konstanta

$\varepsilon$ : Error

\section{HASIL DAN PEMBAHASAN}

Penelitian ini dilakukan untuk mengetahui pengaruh Independensi, Kompetensi, Pelatihan, Pengalaman Kerja, dan Tingkat Pendidikan pada Kinerja Pengawas Koperasi di Kecamatan Buleleng. Tabel 3, berikut menyediakan jumlah penyebaran dan pengembalian kuesuoner.

Tabel 3. Perincian Hasil Penyebaran dan Pengumpulan Data Kuesioner

\begin{tabular}{clcc}
\hline No & \multicolumn{1}{c}{ Uraian } & $\begin{array}{c}\text { Jumlah } \\
\text { Kusioner }\end{array}$ & Persentase \\
\hline & \multicolumn{1}{c}{$(1)$} & $(2)$ & $(3)$ \\
\hline 1 & Total kuesioner yang disebar & 81 & $100 \%$ \\
2 & Kuesioner tidak kembali & 0 & 0 \\
3 & Kuesioner dikembalikan & 79 & $97,5 \%$ \\
4 & Kusioner yang tidak memenuhi kreteria & 2 & $2,5 \%$ \\
& Kusioner yang digunakan dalam analisis & 79 & $97.5 \%$ \\
5 & Tingkat pengembalian kusioner/Respon & $79 / 81 \times$ & $97,5 \%$ \\
& Rate & $100 \%$ & \\
6 & Usable respon rate & $97,5 \%$ & $97,5 \%$ \\
\hline
\end{tabular}

Sumber: Data Penelitian, 2020

Berdasarkan Tabel 3, Dapat dilihat bahwa jumlah kuesioner yang tersebar sebanyak 81 eksemplar dan yang memenuhi kreteria sebanyak 79 eksemplar sisanya 2 kuesioner tidak memenuhi kreteria.

Berdasarkan Tabel 4, menunjukkan bahwa variabel Inpendensi $\left(\mathrm{X}_{1}\right)$ memiliki nilai terendah sebesar 20,00 dan nilai tertinggi sebesar 30,00. Nilai rata- rata dari variabel independensi sebesar 27,00. Nilai standar deviasi sebesar 2,28. Variabel Kompetensi $\left(\mathrm{X}_{2}\right)$ memiliki nilai terendah sebesar 12,00 dan nilai tertinggi sebesar 18,00. Nilai rata-rata dari variabel kompetensi sebesar 16.25. Nilai tersebut menunjukkan bahwa nilai rata-rata mendekati nilai terbesar dari pada nilai terendah, maka hal itu menunjukkan bahwa responden cenderung setuju bahwa kompetensi berpengaruh terhadap kinerja 
pengawas dan nilai standar deviasi sebesar 1,75.

Tabel 4. Hasil Uji Statistik Deskriptif

\begin{tabular}{lccccc}
\hline \multicolumn{1}{c}{ Variabel } & N & Min. & Max. & Mean & $\begin{array}{c}\text { Std } \\
\text { Deviasi }\end{array}$ \\
\hline Independensi $\left(\mathrm{X}_{1}\right)$ & & & & & 2,28 \\
Kompetensi $\left(\mathrm{X}_{2}\right)$ & 79 & 20,00 & 30,00 & 26,84 & 1,75 \\
Pelatihan $\left(\mathrm{X}_{3}\right)$ & 79 & 12,00 & 18,00 & 16,25 & 1,29 \\
Pengalaman Kerja $\left(\mathrm{X}_{4}\right)$ & 79 & 10,00 & 14,00 & 12,89 & 1,80 \\
Tingkat Pendidikan $\left(\mathrm{X}_{5}\right)$ & 79 & 7,00 & 14,00 & 11,83 & 1,54 \\
Kinerja Pengawas Koperasi $(\mathrm{Y})$ & 79 & 7,00 & 13,00 & 10,91 & 2,73 \\
Valid N (listwise) & 79 & 22,00 & 30,00 & 27,12 & \\
\hline
\end{tabular}

Sumber: Data Penelitian, 2020

Variabel Pelatihan $\left(X_{3}\right)$ memiliki nilai terkecil sebesar 10,00 dan nilai terbesar sebesar 14,00. Nilai rata-rata dari variabel pelatihan sebesar 12,89. Nilai tersebut menunjukkan bahwa nilai rata-rata mendekati nilai terbesar dari pada nilai terendah, maka hal itu menunjukkan bahwa responden cenderung setuju bahwa pelatihan berpengaruh terhadap kinerja pengawas dan nilai standar deviasi sebesar 1,29. Variabel Pengalaman Kerja $\left(X_{4}\right)$ memiliki nilai terkecil sebesar 7,00 dan nilai terbesar sebesar 14,00. Nilai ratarata dari varibael pengalaman kerja sebesar 11,83 . Nilai tersebut menunjukkan bahwa nilai rata-rata mendekati nilai terbesar dari pada nilai terendah, maka hal itu menunjukkan bahwa responden cenderung setuju bahwa pengalaman kerja berpengaruh terhadap kinerja pengawas dan nilai standar deviasi sebesar 1,80. Variabel Tingkat Pendidikan $\left(X_{5}\right)$ memiliki nilai terkecil sebesar 7,00 dan nilai terbesar sebesar 13,00. Nilai rata-rata dari variabel tingkat pendidikan sebesar 10,91. Nilai tersebut menunjukkan bahwa nilai rata-rata mendekati nilai terbesar dari pada nilai terendah, maka hal itu menunjukkan bahwa responden cenderung setuju bahwa tingkat pendidikan berpengaruh terhadap kinerja pengawas dan nilai standar deviasi sebesar 1,54.

Berdasarkan Tabel 5, menunjukkan bahwa bahwa variabel Independensi $\left(\mathrm{X}_{1}\right)$ Kompetensi $\left(\mathrm{X}_{2}\right)$, Pelatihan $\left(\mathrm{X}_{3}\right)$, Pengalaman Kerja $\left(\mathrm{X}_{4}\right)$, dan Tingkat Pendidikan $\left(X_{5}\right)$ mempunyai nilai $r$ pearson correlation melebihi dari 0,30 . Jika nilai tersebut melebihi 0,30 maka pernyataan dalam kuesioner tersebut dinyatakan valid.

Uji Validitas dilakukan untuk mengetahui apakah setiap item pertanyaan dinyatakan valid. Setiap item pertanyaan dinyatakan valid apabila nilai Pearson Correlation lebih besar dari 0,30. Berikut ini merupakan hasil dari uji validitas bisa di lihat pada Tabel 5 .

Mengukur atau menentukan apakah suatu kuesioner dianggap andal apabila kuesioner tersebut menjukkan hasil yang sama dari waktu ke waktu. Uji yang dimaksud tersebut adalah Uji Reabilitas yang dapat dilihat dari Tabel 6. 
DEWI, P.R.K. \& LATRINI, M.Y.

Tabel 5. Hasil Uji Validitas

\begin{tabular}{|c|c|c|}
\hline Variabel & Instrumen & Pearson Correlation \\
\hline \multirow[t]{8}{*}{ Independensi $\left(\mathrm{X}_{1}\right)$} & $\mathrm{X} 1,1$ & 0,542 \\
\hline & $\mathrm{X} 1,2$ & 0,532 \\
\hline & $\mathrm{X} 1,3$ & 0,591 \\
\hline & $\mathrm{X} 1,4$ & 0,500 \\
\hline & X1,5 & 0,504 \\
\hline & X1,6 & 0,603 \\
\hline & $\mathrm{X} 1,7$ & 0,615 \\
\hline & $\mathrm{X} 1,8$ & 0,561 \\
\hline \multirow[t]{5}{*}{ Kompetensi $\left(\mathrm{X}_{2}\right)$} & $\mathrm{X} 2,1$ & 0,782 \\
\hline & $X 2,2$ & 0,813 \\
\hline & X2.3 & 0,735 \\
\hline & $X 2,4$ & 0,693 \\
\hline & X2,5 & 0,689 \\
\hline \multirow[t]{4}{*}{ Pelatihan $\left(\mathrm{X}_{3}\right)$} & $\mathrm{X} 3,1$ & 0,737 \\
\hline & $X 3,2$ & 0,735 \\
\hline & $X 3,3$ & 0,596 \\
\hline & $X 3,4$ & 0,783 \\
\hline \multirow[t]{4}{*}{ Pengalaman Kerja $\left(\mathrm{X}_{4}\right)$} & $\mathrm{X} 4,1$ & 0,865 \\
\hline & $X 4,2$ & 0,783 \\
\hline & $X 4,3$ & 0,813 \\
\hline & $X 4,4$ & 0,854 \\
\hline \multirow[t]{4}{*}{ Tingkat Pendidikan $\left(\mathrm{X}_{5}\right)$} & $\times 5,1$ & 0,554 \\
\hline & $X 5,2$ & 0,625 \\
\hline & X5,3 & 0,817 \\
\hline & X5,4 & 0,749 \\
\hline \multirow[t]{8}{*}{ Kinerja Pengawas Koperasi $(Y)$} & Y,1 & 0,689 \\
\hline & $Y, 2$ & 0,615 \\
\hline & $Y, 3$ & 0,732 \\
\hline & $Y, 4$ & 0,708 \\
\hline & Y,5 & 0,736 \\
\hline & $Y, 6$ & 0,619 \\
\hline & $Y, 7$ & 0,662 \\
\hline & $Y, 8$ & 0,740 \\
\hline
\end{tabular}

Sumber: Data Penelitian, 2020

Pada Tabel 6, maka didapatkan kesimpulan bahwa keenama instrument penelitian tersebut telah memiliki nilai koefisien cronbach's alpha melebihi 0,60 yang artinya seluruh pernyataan tersebut dinyatakan konsisten atau reliabel.

Tabel 6. Hasil Uji Reliabilitas

\begin{tabular}{lc}
\hline \multicolumn{1}{c}{ Variabel } & Cronbach's Alpha \\
\hline Independensi $\left(\mathrm{X}_{1}\right)$ & 0,679 \\
Kompetensi $\left(\mathrm{X}_{2}\right)$ & 0,796 \\
Pelatihan $\left(\mathrm{X}_{3}\right)$ & 0,676 \\
Pengalaman Kerja $\left(\mathrm{X}_{4}\right)$ & 0,848 \\
Tingkat Pendidikan $\left(\mathrm{X}_{5}\right)$ & 0,614 \\
Kinerja Pengawas Koperasi $(\mathrm{Y})$ & 0,843 \\
\hline
\end{tabular}

Sumber: Data Penelitian, 2020 
Mengetahui apakah suatu model regresi dinyatakan berdistribusi normal dapat dilakukan dengan Uji Normalitas dimana jika nilai Asymp. Sig (2 -tailed) melebihi $\alpha=0,05$ dapat dilihat pada Tabel 7 .

\section{Tabel 7. Hasil Uji Normalitas}

Kolmogorov-Smirnov Unstandardized Residual

$\mathrm{N} \quad 70$

Asymp. Sig (2-tailed $) \quad 0,79$

Sumber: Data Penelitian, 2020

Berdasarkan Tabel 7, dapat diambil kesimpulan bahwa data berdistribusi normal yang ditunjukkan dengan nilai signifikansi 0,053 yang berarti lebih besar dari 0,05, hal ini yang menyebabkan hasil data berdistribusi normal.

Uji Multikolinieritas dilakukan untuk mengetahui apakah terdapat gejala multikolinieritas. Model regresi yang baik dikatakan apabila model tersebut tidak mengandung gejala multikolinieritas, bisa dilihat pada Tabel 8 .

\section{Tabel 8. Hasil Uji Multikolinieritas}

\begin{tabular}{lcc}
\hline Variabel & Tolerance & VIF \\
\hline Independensi $\left(\mathrm{X}_{1}\right)$ & 0,422 & 2,368 \\
Kompetensi $\left(\mathrm{X}_{2}\right)$ & 0,425 & 2,355 \\
Pelatihan $\left(\mathrm{X}_{3}\right)$ & 0,382 & 2,620 \\
Pengalamn Kerja $\left(\mathrm{X}_{4}\right)$ & 0,634 & 1,576 \\
Tingkat Pendidikan $\left(\mathrm{X}_{5}\right)$ & 0,423 & 2,364
\end{tabular}

Sumber: Data Penelitian, 2020

Berdasarkan Tabel 8, didapatkan kesimpulan bahwa nilai tolerance tidak ada variabel bebas yang menghasilkan nilai tolerance kurang dari 0,10. Perhitungan VIF pada Tabel 8, menunjukkan bahwa tidak ada satupun variabel bebas menghasilkan lebih dari 10. Hal tersebut menunjukkan bahwa tidak ada gejala multikolinieritas antar variabel.

Uji Heteroskedatisitas dilakukan untuk mengetahui apakah terdapat gejala heteroskedatisitas. Model regresi yang baik dikatakan apabila model tersebut tidak mengandung gejala heteroskedatisitas dan nilai signifikannya harus melebihi 0,05 yang bisa dilihat pada Tabel 9, berikut.

Tabel 9. Hasil Uji Heteroskedatisitas

\begin{tabular}{ll}
\hline \multicolumn{1}{c}{ Variabel } & Signifikansi \\
\hline Independensi $\left(\mathrm{X}_{1}\right)$ & 0,620 \\
Kompetensi $\left(\mathrm{X}_{2}\right)$ & 0,352 \\
Pelatihan $\left(\mathrm{X}_{3}\right)$ & 0,276 \\
Pengalaman Kerja $\left(\mathrm{X}_{4}\right)$ & 0,066 \\
Tingkat Pendidikan $\left(\mathrm{X}_{5}\right)$ & 0,827
\end{tabular}

Sumber: Data Penelitian, 2020

Pada Tabel 9, didapatkan kesimpulan bahwa nilai signifikansi setiap 
variabel bebas tersebut berada diatas 0,05 . Sehingga hal tersebut menunjukkan bahwa tidak ada gejala heteroskedatisitas dalam model regresi tersebut.

Tabel 10. Hasil Analisi Regresi Linier Berganda

\begin{tabular}{llllll}
\hline Variabel & \multicolumn{1}{c}{$\begin{array}{c}\text { Unstandardized } \\
\text { Beta }\end{array}$} & Std. Error & Beta & T & Sig. \\
\hline Konstanta & 0,728 & 2,077 & & 0,350 & 0,727 \\
Independensi & 0,230 & 0,108 & 0,192 & 2,135 & 0,036 \\
Kompetensi & 0,324 & 0,140 & 0,207 & 2,312 & 0,024 \\
Pelatihan & 0,654 & 0,200 & 0,310 & 3,276 & 0,002 \\
Pengalaman Kerja & 0,231 & 0,111 & 0,153 & 2,081 & 0,041 \\
Tingkat & 0,334 & 0,159 & 0,189 & 2,100 & 0,039 \\
Pendidikan & & & & & \\
R square & 0,751 & & & & \\
Fhitung & 43,959 & & & & \\
Sig. Fhitung & 0,000 & & & &
\end{tabular}

Sumber: Data Penelitian, 2020 berikut.

Berdasarkan Tabel 10, dapat disusun persamaan regresi sebagai

$$
\mathrm{Y}=0,728+0,230_{1}+0,324_{2}+0,654_{3}+0,231_{4}+0,334_{5}+\varepsilon
$$

Berdasarkan persamaan di atas, dapat dijelaskan sebagai berikut. Nilai konstanta (a) sebesar 0,728 mengandung arti jika nilai variable bebas yaitu independensi $\left(X_{1}\right)$, kompetensi $\left(X_{2}\right)$, pelatihan $\left(X_{3}\right)$, pengalaman Kerja $\left(X_{4}\right)$, tingkat pendidikan $\left(X_{5}\right)$ tidak berubah (nol), mengakibatkan kinerja pengawas koperasi (Y) konstantanya sebesar 0,728 . Nilai $\beta_{1}$ untuk variabel independensi $\left(X_{1}\right)$ sebesar 0,230 yang artinya variabel independensi meningkat menyebakan kinerja pengawas koperasi $(\mathrm{Y})$ akan mengalami peningkatan dengan asumsi variable lainnya sama dengan nol. Nilai $\beta_{2}$ untuk variabel kompetensi $\left(X_{2}\right)$ sebesar 0,324 yang artinya variabel kompetensi meningkat menyebabkan kinerja pengawas koperasi $\mathrm{Y}$ ) akan mengalami peningkatan dengan asumsi variable lainnya sama dengan nol. Nilai $\beta_{3}$ untuk variabel kompetensi $\left(X_{3}\right)$ sebesar 0,654 yang artinya variabel kompetensi meningkat menyebakan kinerja pengawas koperasi akan mengalami peningkatan dengan asumsi variable lainnya sama dengan nol. Nilai $\beta_{4}$ untuk variabel kompetensi $\left(\mathrm{X}_{4}\right)$ sebesar 0,231 yang artinya variabel kompetensi meningkat menyebakan kinerja pengawas koperasi akan mengalami peningkatan dengan asumsi variable lainnya sama dengan nol. Nilai $\beta_{5}$ untuk variabel kompetensi $\left(X_{5}\right)$ sebesar 0,334 yang artinya variabel kompetensi meningkat menyebabkan kinerja pengawas koperasi akan mengalami peningkatan dengan asumsi variable lainnya sama dengan nol.

Didapatkan kesimpulan pada Tabel 10, bahwa nilai Adjusted R-Square sebesar 0,751yang berarti bahwa 75,1\% variasi kinerja pengawas koperasi di pengaruhi oleh Indpendensi, Kompetensi, Pelatihan, Pengalaman Kerja, Tingkat Pendidikan sebesar $24,9 \%$ dipengaruhi oleh faktor-faktor lainnya. Berdasarkan Tabel 10, menunjukkan bahwa hasil nilai $\mathrm{F}$ sig $=0,000<a=0,05$ yang artinya model regresi tersebut layak digunakan untuk menguji variabel 
independen terhadap variabel dependen.

Hasil Uji $\mathrm{t}$ pada hipotesis pertama dari penelitian untuk variabel independensi nilai sig sebesar 0,036 < 0,05, yang berarti independensi berpengaruh positif pada kinerja pengawas koperasi. Semakin tinggi independensi yang dimiliki pengawas maka akan semakin baik kinerja yang dihasilkan. Jika seorang pengawas bekerja secara independen maka nantinya akan berdampak baik bagi jalannya operasional koperasi. Hasil penelitian ini sejalan dengan beberapa penelitian terdahulu yang dilakukan oleh (Kodyawati \& Dewi, 2019) menunjukkan bahwa independensi berpengaruh positif terhadap kinerja pengawas koperasi. Hal ini serupa juga yang ditemukan oleh (Prawitasari \& Badera, 2015) yang menunjukkan bahwa independensi berpengaruh positif terhadap kinerja pengawas dan (Putu \& Desyanti, 2008) juga mengemukan bahwa independensi terbukti berpengaruh positif terhadap kinerja auditor, yang dapat disimpulkan bahwa semakin tinggi independensi auditor maka kinerja auditor yang dihasilkan akan semakin baik.

Hipotesis kedua untuk variabel kompetensi nilai sig sebesar 0,024 >0,05 yang berarti kompetensi berpengaruh positif pada kinerja pengawas koperasi. Semakin tinggi kompetensi yang dimiliki pengawas maka akan semakin baik kinerja yang dihasilkan. Hasil penelitian ini sejalan dengan beberapa penelitian terdahulu yang dilakukan oleh (Putra \& Rasmini, 2014) menyatakan bahwa kompetensi berpangruh positif pada efektivitas pengendalian intern koperasi. (Tjun et al., 2012) menyatakan bahwa kompetensi berpengaruh positif terhadap kualitas audit. (Alim et al., 2007) menyatakan bahwa kompetensi berpengaruh positif terhadap kualitas audit. Semakin tinggi semakin tinggi kompetensi auditor akan semakin baik kualitas hasil pemerikasaannya. Dengan memiliki kompetensi dalam jasa profesinya, maka akan mempengaruhi laporan hasil pemeriksaan yang merupakan salah satu penilaian terhadap kinerja pengawas.

Hipotesis ketiga untuk variabel pelatihan nilai sig $\mathrm{t}$ sebesar 0,002 >0,05 yang berarti pelatihan berpengaruh positif pada kinerja pengawas koperasi. Semakin sering pengawas melakukan pelatihan maka akan semakin baik kinerja yang dihasilkan. Hasil penelitian ini sejalan dngan beberapa penelitian terdahulu yang dilakukan oleh (Putra \& Rasmini, 2014) menyatakan bahwa pelatihan perpengaruh positif terhadap kinerja pengawas. Menurut (Andayani \& Makian, 2016) menyatakan bahwa pelatihan berpengaruh positif terhadap kinerja karyawan. Menurut (Widyantara et al., 2017) juga menyatakan dalam penelitiannya pelatihan berpangaruh positif terhadap kinerja badan pengawas LPD di Kecamatan Buleleng. Dengan mengikuti pelatihan secara rutin akan mempengaruhi kualitas kerja yang dihasilkan oleh pengawas.

Hipotesis keempat untuk variabel pengalaman nilai sig sebesar 0,041 > 0,05 yang berarti pengalaman kerja berpengaruh positif pada kinerja pengawas koperasi. Semakin banyak pengalaman kerja yang dimiliki pengawas makan akan semakin baik kinerja yang dihasilkan. Hasil penelitian ini sejalan dengan beberapa penelitian terdahulu yang dilakukan oleh (Kodyawati \& Dewi, 2019) menujukkan bahwa pengalaman yang dimiliki 
seorang auditor dapat berpengaruh signifikan terhadap kualitas audit yang disajikan oleh seorang auditor. (Budiasih \& Budiartha, 2017) dalam penelitiannya menyatakan bahwa pengalaman kerja berpengaruh positif terhadap kinerja auditor. (Widyantara et al., 2017) juga menyatakan dalam penelitiannya pengalaman kerja berpangaruh positif terhadap kinerja badan pengawas LPD di Kecamatan Buleleng

Hipotesis kelima untuk variabel tingkat pendidikan nilai sig sebesar 0,039> 0,05 yang berarti tingkat pendidikan berpengaruh positif pada kinerja pengawas koperasi. Semakin baik tingkat pendidikan yang dimiliki pengawas maka akan semakin baik kinerja yang dihasilkan. Hasil penelitian ini sejalan dngan beberapa penelitian terdahulu yang dilakukan oleh (Dubis et al., 2010) dan (Moyes, 2007) menyatakan bahwa pendidikan berpengaruh positif terhadap kinerja auditor. (Widyantara et al., 2017) juga menyatakan dalam penelitiannya tingkat pendidikan berpangaruh positif terhadap kinerja badan pengawas LPD di Kecamatan Buleleng.

\section{SIMPULAN}

Variabel independensi, kompetensi, pelatihan, pengalaman kerja dan tingkat pendidikan berpengaruh positif pada kinerja pengawas koperasi di Kecamatan Buleleng, semakin meningkat independensi, kompetensi, pelatihan, pengalaman kerja dan tingkat pendidikan yang dimiliki pengawas maka semakin meningkatkan kinerja pengawas koperasi di Kecamatan Buleleng. Peneliti selanjutnya yang ingin melakukan penelitian sejenis dapat memilih sampel koperasi yang berada di Kecamatan lain serta penelitian selanjutnya dapat menggunakan rentan waktu lebih panjang karena peneliti hanya menggunakan rentan waktu 3 tahun.

\section{REFERENSI}

Afroz, N. N. (2018). Effects of Training on Employee Performance: A Study on Banking Sector, Tangail Bangladesh. Global Journal of Economic and Business, 4(1), 111-124. https:// doi.org/10.12816/0048158

Agustia, R., \& Pertiwi, N. P. (2013). Pengaruh Kompetensi, Independensi, Profesionalisme Terhadap Kualitas Audit. TEKUN: Jurnal Telaah Akuntansi Dan Bisnis, 21. https:/ / doi.org/10.22441/tekun.v8i1.5528

Akbar, A. G. (2019). The Impact of a Procurement Implementation and Government Internal Control System on Goods/Services Procurement Fraud Prevention by Using Organization Ethical Culture as a Moderating Variable. Jurnal Economia, 15(1), 69-81. https:// doi.org/10.21831/economia.v15i1.23618

Alim, M. N., Hapsari, T., \& Purwanti, L. (2007). Pengaruh Kompetensi Dan Independensi Auditor Terhadap Kualitas Audit Dengan Etika Auditor Sebagai Variabel Moderasi. Simposium Nasional Akuntansi. https:// doi.org/10.35141/jraj.v1i2.60

Allen, M. F., Linville, M., \& Stott, D. M. (2005). The Effect of Litigation on Independent Auditor Selection. America Journal of Business, 21 (1), 37.

Andayani, N. R., \& Makian, P. (2016). Pengaruh Pelatihan Kerja dan Motivasi Kerja Terhadap kinerja Karyawan Bagian PT. PCI Elektronik International 
(Studi pada Karyawan PT. PCI Elektronik Internasional). Jurnal Akuntansi, Ekonomi Dan Manajemen Bisnis, 4(1), 41-46.

Badara, M., \& Saidin, S. (2013). The relationship between audit experience and internal audit effectiveness in the public sector organization. International Journal of Academic Research in Accounting Finance and Management Sciences, 3 (3), 329-339. Retrieved from http://dx.doi.org/10.6007/IJARAFMS/v$3 \mathrm{i} 3 / 224$

Bhat, Z. . (2013). Impact of Tranning on Employee Performance: A Study of Retail Banking Sektor in India. Indian Journal of Applied Research, 3(6), 292-293.

Bliss.B.A., Partnoy, F., \& Furchtgott, M. (2017). International bundling and securities litigation. Journal of Accounting and Econimic, 1-24. Retrieved from https:// doi.org/10/1016/j.jacceco.2017.11.013

Bouhwai M, I., \& Zaki, B. (2015). The effect of Working Experience (Survey State Owned Companies In Libya). IOSR Journal Of Economics and Finance (IOSR_JEF), 6(4), 60-67.

Budiasih, I. G. A. A., \& Budiartha. (2017). Kemampuan Auditor Tenure Memoderasi Hubungan Pengalaman dan Skeptisme Auditor dengan Kualitas Audit. Jurnal Ilmiah Akuntansi, 2 (1), 53-70.

Bullen, M. L., \& Eyler, K.-A. (2010). Human resource accounting and international development: implication for measurement of International Business and Cultural Studies. Journal Economic.

Cloyd, \& C Bryan. (1997). Perfomance in Research Task: The Joint Effect of Knowledge and Accountability. Journal of Accounting, 22, 111-131.

Dewi, A. S. (2013). Pengaruh Independensi, Kecakapan, Profesional, Obyektifitas, Kompetensi, dan Pengalaman Kerja Terhadap Kualitas Hasil Audit (Studi empiris pada pemerintah kota surakarta dan kabupaten Wonogiri. Journal of Accounting, 7(1), 48-60.

Dubis, G., Jain, P., Machanda, A., \& Thakkar, R. (2010). Measuring internal audit effectiviness and effciency: practice guide. Institute of Internal Auditors, IIA, $1-16$.

Ferracuti, E., \& Stubben, S. . (2019). The Role of Financial Reporting in Resolving Uncertainty about Corporate Invesment Opportunities. Journal of Accounting and Econimic, 1-25. Retrieved from https:/doi.org/10/1016/j.jacceco.2019.101248

Kalbers, L., \& P.T. Fogarty. (1995). Professionalism and Its Consequences: A Study of Internal Auditor. Journal of Accounting, 14 (1).

Kartika, L. N., \& Sugiarto, A. (2014). Pengaruh Tingkat Kompetensi Terhadap Kinerja pegawai Administrasi Perkantoran. Jurnal Ekonomi Dan Bisnis, 17 (1), 73-89.

Kodyawati, P., \& Dewi, L. G. K. (2019). Pengaruh Independensi Keahlian Profesi Motivasi Kerja Pengalaman Kerja Dan Tingkat Pendidikan Terhada[ Kinerja Pengawas Koperasi. E-Jurnal Akuntansi Universitas Udayana, 27, 1597-1627.

Mansouri, A., Pirayesh, R., \& Salehi, M. (2011) . Audit Competence and Audit Quality: Case in Emerging Economy. International Journal of Business and Management, 4 (2), 17-25

Moyes, G. (2007). The defferences in perceived level of fraud-detecting effectiviness of SAS No. 99 red flags between external and internal auditor. 
Journal of Business and Economic Research, 5 (6), 9-26. Retrieved from http:/ / dx.doi.org/10/19030/jber.v5i6.2551

Murtini, N. N., \& Juliarsa, G. (2017). Pengaruh Independensi, Keahlian Profesional, Pengalaman Kerja, Dan Tingkat Pendidikan Pada Kinerja Pengawas Koperasi. E-Jurnal Akuntansi, 20, 1390-1418. https:// doi.org/10.24843/EJA.2017.v20.i02.p19

Nusabali. com. (n.d.). 24 Koperasi Menyerah di Buleleng. Retrieved from http://www.nusabali.com/berita/39455/24-koperasi-di-bulelengmenyerah

Prawitasari, P., \& Badera, I. (2015). Pengaruh Independensi, Keahlian Profesional, Dan Pengalaman Kerja Pada Kinerja Pengawas Koperasi Serba Usaha. E-Jurnal Akuntansi, 11(1), 15-28.

Putra, P. B. S., \& Rasmini, N. K. (2014). Pengaruh Independensi, Kompetensi, dan Ruang Lingkup Pekerjaan Audit Pengawas pada Efektivitas Pengendalian Intern Koperasi. E-Jurnal Akuntansi Universitas Udayana, 8(3), 371-384.

Putu, N. I., \& Desyanti, E. K. A. (2008). Pengaruh Independensi, Keahlian Profesional, Dan Pengalaman Kerja Pengawas Intern Terhadap Efektivitas Penerapan Struktur Pengendalian Intern Pada Bank Perkreditan Rakyat Di Kabupaten Badung. Jurnal Ilmiah Akuntansi Dan Bisnis.

Sofia, I. P., \& Murwaningsari, E. (2019). The Role of Corporate Diversification, Capital Stucture Determinat and Structure of Ownership on Earning Management with Information Asymmetry as Moderating Variabel. Research Journal of Finance and Accounting, (10(14)), 45-51.

Tjun, L. T., Marpaung, E. I., \& Setiawan, S. (2012). Pengatuh Kompetensi dan Independensi Auditor Terhadap Kualitas Audit. Jurnal Akuntansi, 4(1), 3356. https://doi.org/10.1177/1753193416664491

Widyantara, I. N., Wahyuni, M. A., \& Atmadja, A. T. (2017). Pengaruh Independensi, Motivasi, Kompetensi, Dan Pengalaman Kerja Terhadap Kinerja Badan Pengawas Sebagai Auditor Internal Pada Lembaga Perkreditan Desa (Lpd) Di Kecamatan Buleleng. JIMAT (Jurnal Ilmiah Mahasiswa Akuntansi) Undiksha, 1(Vol 8, No 2 (2017):). Retrieved from https://ejournal.undiksha.ac.id/index.php/S1ak/article/view/13278 